\title{
Performance and stability of the sectors in the food industry of Czech Republic
}

\author{
Eva Kostikov \\ Department of Finance, University of Finance and Administration \\ Czech republic \\ evacipovova@gmail.com
}

\section{David Mareš}

Department of Finance, University of Finance and Administration

Czech republic

mares.dav@volny.cr.

\section{Radka Procházková}

Department of Statistics, Czech University of Life Sciences Prague

Czech republic

procharkova@pef.cru.cr.

Abstract. This article deals with performance, stability and predictions for the individual sectors of the food industry in Czech Republic basing on the statistical data for the years 2005-2015. The goal of the article is to provide reasons for individual changes, i.e., to determine the key factors which have influence on the performance and stability of individual sectors, to point to the stability of individual sectors and at the same time to predict their performance in the future. The conclusion has been reached that bakery, confectionary and other flour-based products and Other food products are the best performing areas in the given branch and that Meat and meat products,. Fish, crustaceans and molluscs, Dairy products, Other food products and Industrial feeds will increase their performance in the future, while other areas in the branch which have been subjected to statistical analysis are expected to experience a fall in performance

Keywords: accounting value added, Czech Republic, prediction, time series.

JEL Classification: Q17, Q18, C5, D40 


\section{INTRODUCTION}

As in the entire European Union (EU), food production in Czech Republic (CR) is one of the principal branches of the processing industry (the Ministry of Agriculture report, 2016). Given the widespread segmentation of individual sectors in the food industry, we have decided to analyse those individual sectors in the food industry which have a narrower economic focus. The goal of this article is to evaluate the stability of individual sectors in the food industry and to provide reasons for individual changes in the performance (stability) of individual sectors which have occurred throughout history and at the same time to predict the performance of these individual sectors in the future, including from the point of view of an investor who wishes to enter the given sector or from the point of view of a company owner who wants to know about the stability and performance of his or her sector. The authors are also aware of other aspects which can be used to view the given branches, for example, from the viewpoint of self-sufficiency of CR in production of basic food products, where the falling share of domestically processed products in domestic consumption and exports signalises a loss of the competitive position for some of the basic sectors in the processing industry (Bašek, 2010). However, this point of view is not the subject of this article. Prášilová, Procházková and Hošková (2016) are currently involved in investigating the issue of self-sufficiency in the production of basic food products in CR. The authors have decided to measure the stability of individual branches in the food industry due to the fact that food is influenced by global phenomena, trends and challenges which are projected into the risk factors, something which has already shown itself to be true in the entire agricultural branch. "The agricultural branch is characterized by a high level of risk. This has always been the case, but recently there has been a tendency for increased risk” (Jankelova, Masar \& Moricova, 2017).

\section{LITERATURE REVIEW}

Accounting value added has been selected as the method of measuring the performance and stability of the individual branches. Added value is then defined as (revenues for the sale of goods + revenues for the sale of own products and services + the change in inventory through own activities + activation) performance consumption (the consumption of materials + services) - the costs outlaid for the sold goods. We can, therefore, characterise added value as a differential performance indicator with a direct link to the market (the market represents the revenues here) and the costs directly associated with the creation of products (the consumption of materials and services, the costs outlaid on the sold goods). The added value indicator is therefore a suitable indicator of a company's performance which is directly connected with the situation in the market (costs) as well as the outputs (revenues), i.e. "Added value is defined here as the difference in the economic value between the physical inputs and performance of a production process and it is generally analysed at the firm or national economy level." (Roger \& Leif, 2009)

We can, therefore, characterise the added value indicator as an indicator which is sensitive to the variable situation in the market both from the point of view of the revenues and the costs. Added value is also a suitable indicator of the effectiveness of the business, for example, in the case of markets with a high degree of volatility. "We can assume significant differences in the reactions to changing internal or external economic environments within a branch." (Volek and Novotná, 2014) The suitability of the use of added value as a sensitive indicator has also been discussed in a wider sense (Kraftova, Mateja and Prasilova, 2011). Nevertheless, before selecting the accounting value added, the authors also acquainted themselves with other methods for measuring the performance and stability of the food industry, including the foreign trade balance, the number of employees, sales etc. (Náglová and Horáková, 2016), market concentration, sales etc. (Blažková, 2016), the comprehensive financial analyses which are applied 
to the dairy industry (Špička, 2013) or to selected branches of the food industry (Mejstríḱková, Mezera \& Plášil, 2011) or research undertaken by international authors who have focussed on the ROA (Return on Assets) indicator and analysed, for example, soft factors such as strategy, competition, etc. (Baker, 2003).

Nevertheless, the authors have inclined towards accounting value added, which has already been applied in the case of forest product industries (Roger \& Leif, 2009) and the sawmilling industry of Peninsular Malaysia (Pang, H'ng, Chai, Lee \& Paridah, 2015) or in the case of use in an entire branch (Gupta \& Kumar, 2013). Accounting value added is also used as an economic indicator in the food manufacturing industry in South Carolina (Bolotova, 2016). The following quote also speaks to the significance of accounting value added as a performance indicator in agriculture: "This indicator is the difference between the value of the performance and the costs of the intermediate inputs or intermediate consumption. Value-added data can be used in monitoring and evaluating the performance of agricultural holdings, farms and agribusinesses and provides a measurement for measuring their economic contribution to the national economy." (Daniloska, 2016) The Curran (2012) study also speaks of the fact that accounting value added is also a significant indicator in relation to the economy as a whole, for example when measured using GDP.

The authors are also aware of other major influences, including culture and personal values (see Kaasa, 2019), the importance of the accounting information system, which represents institutional modernisation in agriculture companies (see Muhammad et al., 2019), macroeconomic trends mentioned in Formánek (2019) and Maciejewski and Wach (2019), changes in demand, etc. However, with respect to the scope of the article, availability of data and the explanatory power of the results of the statistical analysis, it was not possible to take all factors into account.

\section{METHODOLOGY}

The aim of this paper is to construct a development prediction model for the extent and structure of the book value added in the food industry sectors. Two exponential smoothing methods have been applied to the forecasts for non-seasonal time series with a local linear trend (the Holt method) and double exponential smoothing (the Brown method).

Due to the required length of the paper, the authors focused on the assessment of performance and stability of the individual sectors of the food industry in the Czech Republic based on the development of accounting value added, working with one-dimensional models of time series. The statistical model did not consider the effect of other factors. The goal was neither to construct an econometric model. Moreover, quantification of the effect of a number of other factors would also be problematic due to data unavailability. In addition, a comparison with the development in EU countries would also mean that the article would exceed the required length.

Therefore, the applied statistical methods were based on data that was available in the form of time series. Adaptive time series models belong among advanced statistical methods. This type of models respond quickly to structural changes that occur over time and are very useful in predicting the behaviour of time series that are characterized by irregularities and trend breaks.

\subsection{The data source}

The statistical analysis here is mostly based on the reports published by the Ministry of Agriculture of the Czech Republic. The use of advanced statistical methods from the area of adaptive approaches to time series analysis and the long-term development tendencies of accounting value added in the food industry structure over the 2005-2015 period have been described. (The data for 2016 and 2017 was- not available at the time of writing) 


\subsection{The analytical smoothing of time series}

In addition to trend functions, adaptive models have also been applied to the trend description. Models of this type react quickly to structural changes occurring in time and they are very useful for predicting the future course of a time series loaded with irregularities and breaks in the trend. The adaptive models started from the assumption that the latest data in a time series is the most valuable for the construction of the future development forecast (Hindls, Hronová, Seger \& Fischer, 2008). One adaptive approach has been exploited in the present study, namely the exponential smoothing method. The parameter estimates can be obtained using the least-squares method in the following equation:

$$
\sum_{k=0}^{n-1}\left(y_{n-k}-T_{n-k}\right)^{2} w_{k}=\min ,
$$

where yn-k are the empirical values at the (n-k) moment; $\mathrm{k}=0,1, \ldots, \mathrm{n}-1$ is the age of the data at the moment $\mathrm{n}$; Tn-k is the trend component at a time $(\mathrm{n}-\mathrm{k})$; wk are the weights which are inversely proportional to the "age" of the data, i.e. the weight decreases as the age increases. It is assumed that the wk weight is an exponential function of the type

$$
w_{k}=\alpha^{k}, \quad 0<\alpha<1, \quad k=0,1, \ldots, n-1,
$$

where the $\alpha$ quantity is the balancing constant. As is clear from the relationship (2), the wk weights are an exponential function of the age of the data. Estimates of the Tn-k trend model component can be obtained using the minimized expression:

$$
\sum_{k=0}^{n-1}\left(y_{n-k}-T_{n-k}\right)^{2} \alpha^{k} \ldots . . \min .
$$

Two exponential smoothing methods have been usedto predict the Tn- $\mathrm{k}$ trend type. The Brown method with the $\alpha$ smoothing constant from the $(0 ; 1)$ interval has been used for non-seasonal time series with a constant trend in short sections of the series. A double exponential smoothing procedure was used, if the trend was approximately linear in the short sections. In case of the Holt smoothing procedure, two smoothing constants, $\alpha$ and $\gamma$, have been estimated from the $(0 ; 1)$ interval:

$$
\alpha_{\text {Holt }}=\alpha(2-\alpha) ; \quad \gamma_{\text {Holt }}=\frac{\alpha}{2-\alpha}
$$

The $\alpha$ parameter adjusts the level of adaptation and it means that the higher its value, the faster the method reacts to changes in the data. The $\gamma$ parameter defines the level of smoothing for the local linear trends (Montgomery, Jennings \& Kulahci, 2008).

The following recurrence relations apply when modelling the series using these models:

$$
\begin{aligned}
& S_{t}=\alpha y_{t}+(1-\alpha) \cdot\left(S_{t-1}+T_{t-1}\right), \\
& T_{t}=\gamma\left(S_{t}-S_{t-1}\right)+(1-\gamma) \cdot T_{t-1}, \\
& \hat{y}_{t}=S_{t} .
\end{aligned}
$$

Real economic criteria should form the basis for the decision-making based on the appropriate type of trend function. This paper offers a criterion based on a comparison of the sums of the squares of the deviations of the empirical time series values from the smoothed ones - Mean Absolute Percent Error (MAPE):

$$
\text { MAPE }=\frac{100}{\mathrm{n}} \sum_{t=1}^{n} \frac{\left|\mathrm{y}_{\mathrm{t}}-\mathrm{y}_{\mathrm{t}}^{\prime}\right|}{\mathrm{y}_{\mathrm{t}}}
$$


$y_{t}, y_{t}^{\prime} \ldots$ empirical and smoothed $t$. s. values.

The model with the lowest MAPE criterion values is generally preferred. Icon charts, which enabled the visualisation of multidimensional data, have been used to present the results of the statistical analyses (Chernoff faces). The statistical computations were performed in the STATISTICA software environment (13.2 US version).

\section{EMPIRICAL RESULTS AND DISCUSSION}

The production of food products and the production of beverages according to the CZ-NACE system is significantly segmented from the point of view of the sectors, because it processes many agrarian commodities, both of plant and animal origins, and satisfies various groups of consumers. As such, a decision was made to analyse the individual sectors separately; see the table below.

We also decided not to compare the individual production sectors in the Czech Republic with other countries - sectors in the EU as different countries have different levels of subsidies, different climate conditions, different traditions and dietary practices - these factors make it impossible to compare productivity between individual countries and compare it to the EU as a whole.

Table 1

The production sectors - divisions or their groups according to the CZ-NACE system

\begin{tabular}{|l|l|}
\hline 10 & Food production \\
\hline 10.1 & Meat and meat products; \\
\hline 10.2 & Fish, crustaceans and molluscs, \\
\hline 10.3 & Fruit and vegetables; \\
\hline 10.4 & Vegetable and animal oils and fats; \\
\hline 10.5 & Dairy products; \\
\hline 10.6 & Mill and starch products; \\
\hline 10.7 & Bakery, confectionery and other flour-based products; \\
\hline 10.8 & Other food products; \\
\hline 10.9 & Industrial feeds. \\
\hline
\end{tabular}

Source: the Ministry of Agriculture report for 2016

\subsection{Accounting value added in the individual sectors of the food industry in the CR}

There were 5 key sectors or groups of products (with a share in excess of 10\%) from the point of view of the production performance in the analysed years of 2005 - 2015. They were CZ-NACE - 10.1, 10.8, 10.5, 10.9 and 10.7. The shares of other products were lower; they accounted for approximately $12.66 \%$ of the structure at the beginning of the monitored period (2005) and approximately $9.35 \%$ at the end of the period (2015).

\subsubsection{Accounting value added in the meat and meat product sector (10.1)}

The meat and meat product sector (10.1) fell to its minimum in 2012 (8,012.6 million CZK). The average year-on-year fall in the 2009-2012 period amounted to 5.6\%. An average year-on-year increase in the accounting value added of more than $8 \%$ then occurred in this sector from the pivotal year of 2012. In 2014 and 2015, the accounting value added in the meat and meat product sector stabilised at around 9,400 million CZK. 
Given the non-material changes in the meat and meat product sector, we can consider the sector to be stable without any substantial fluctuations in added value.

\subsubsection{The accounting value added in the fish, crustacean and mollusc sector (10.2)}

The 10.2 Fish, crustacean and mollusc sector recorded a stepwise increase in performance at the turn of 2009 - 2010. The accounting value added more than tripled in 2010 (an increase of 225.8\%). There was a year-on-year drop of $18 \%$ in the following years. The accounting value added in the Fish, crustacean and mollusc sector was then in the area of 400 million CZK in 2012-2015.

If we look at the price development as expressed by the fish, crustacean and mollusc producer price index, it is apparent that prices did not rise in 2010 in comparison with 2009 (the Ministry of Agriculture report for 2011). This means that the growth in added value in 2010 was based on increased sales of products which can also be observed in the profit and loss statement (the Ministry of Agriculture report for 2011) which includes an increase in the revenues for the sale of goods (the import and sale of fish) (5.35\% growth; see the Ministry of Agriculture report for 2011), but mainly growth in the revenues for the sale of own products by $252.32 \%$. We compared 2010 and 2009, from which it is possible to infer the popularity of Czech carp among Czech citizens given the negative trade balance in 2010 (the Ministry of Agriculture report for 2016).

\subsubsection{The accounting value added in the fruit and vegetable sector (10.3)}

The fruit and vegetable sector (10.) has reported a permanent fall in performance since 2006, whereby there was a slight revival in 2014 and 2015 when the accounting value added rose from its minimum of 2013 (1,349.4 million CZK) by almost 7\% to a value of around 1,445 million CZK.

The fall is not considered to be material given its amount and the sector can be seen as stable, as far as the development of the added value is concerned.

\section{(10.4)}

4.1.4. The accounting value added in the vegetable and animal oil and fat sector

The vegetable and animal oil and fat sector (10.4) reported its greatest drop between 2009 and 2010 when the accounting value added fell by $58 \%$. A further fall of $35.6 \%$ then occurred in 2012 . Since then, it has oscillated around the value of 1,200 million CZK.

The reason for the fall in the book value in 2010 was an increase in inputs, particularly for rapeseed. The sector was not able, however, to proportionately transfer this increase into a higher price for its customers and the given price level and production led to a disproportionate rise in the costs for the sold goods in relation to revenues from the sale of goods, i.e. the costs for the sold goods contributed to the revenues for the sold goods to a greater extent and this led to a fall in the sales margin. This difference was not even alleviated by the greater difference between performance and performance consumption, which is apparent from the Ministry of Agriculture reports for 2016 and 2011. The same reasons stood behind the fall in 2012 when the price of sunflower seed in the Czech Republic reached the level of 10,477 CZK/t in 2012 (the Ministry of Agriculture report for 2011).

Here too, we can find an oligopolistic market structure. "The Czech fat industry is relatively highly concentrated. The average number of business subjects which is involved in the production of plant and animal oils and fats is relatively low." (the Ministry of Agriculture report for 2011)

From the point of view of stability, there is a visible threat here in the form of an input, that being the price for rapeseed in relation to the significant drop in accounting value added and as such we can 
consider the given branch to be unstable and the added value to be under threat, especially on the input side.

\subsubsection{The accounting value added in the dairy product sector (10.5)}

Dairy products (10.5) showed significant fluctuations in the 2005-2015 period. On average, it is possible to consider the trend in dairy product production to be one of growth. The accounting value added for this processing sector fell to a minimum in 2006, when it amounted to less than 4.5 billion CZK. The biggest year-on-year increase in accounting value added for the entire monitored period was recorded in the following year, 2007; a growth of almost one third (32.2\%). The accounting value added for this sector did not then dip below 5 billion CZK from 2007 to 2015 and it reached its maximum in 2013 (6,020.2 million CZK). In the last analysed years, it fluctuated around 5.5 billion CZK. In 2015, the sector contributed $11.1 \%$ to the creation of added value with regard to overall food production; this involved a slight year-on-year increase from 10.0\% in 2014.The fall to the minimum in 2006 was caused by milk quotas and increased foreign competition in the domestic market (increased imports) (the Ministry of Agriculture report for 2017). "The growth in added value in 2007 was caused by growth in the demand for dairy products in the international and European markets." (the Ministry of Agriculture report for 2008) The growth in added value on dairy products in 2013 in the CR was caused by the low supplies of international dairy products. The increased dairy production in the CR meant that this fact had a positive impact on the higher added value (the Ministry of Agriculture report for 2014).

\subsubsection{The accounting value added in the mill and starch product sector (10.6)}

The accounting value added on mill and starch products (10.6) displayed a very similar development to sector 10.7. A fall was recorded here as a consequence of increased costs for the sold goods (business activity), which resulted in a fall in the sales margin. This means that the costs for the acquisition of the products from the business activity increased. This was the main motor for the fall in added value because the difference between the performance and the performance consumption was greater than in the previous year (the Ministry of Agriculture report for 2015).

The fall in added value was mainly caused by Council Regulation (EC) No 79/2009 which decided to end the joint organisation of the starch market and the associated regulations pertaining to the cultivation of starch potatoes from the harvest of 2012. The production of potato and wheat starch has a long domestic tradition. In 2013, the area of potatoes planted for starch production was reduced year-on-year from 3,402 ha to 3,366 ha. $19.5 \%$ fewer potatoes were processed than in 2012, the hectare yield fell by $18.8 \%$ to $26.7 \mathrm{t} / \mathrm{ha}$ and the starch yield per hectare fell in comparison with the previous year of 2012 by $19.5 \%$ to an average of $5.72 \mathrm{t}$. The starch content of the potatoes remained at approximately the same level $(18.4 \%)$ in comparison with 2012. The production of starch fell year-on-year by $19.5 \%$ to 19.25 thousand t. (the Ministry of Agriculture report for 2014)

Nevertheless, it is also possible to find an oligopolistic structure in this market which is mainly represented by companies focussed on the production of potato starch and wheat starch.

\subsubsection{The accounting value added in the bakery, confectionery and another flour- based product sector $(C Z-10.7)$ and the other food product sector $(C Z-10.8)$}

The accounting value added for bakery, confectionery and other flour-based products (10.7) in conjunction with the accounting value added for other food products (10.8) accounts for almost half $(47 \%)$ of the total added value in the food industry (data for 2015). 
From the point of view of added value, we can consider this branch to be the most efficient and the strongest in the food industry, which is demonstrated by the overall revenues in the food industry. Nevertheless, we have to take into account what is said about the sector (10.7) "Last year, it increased by 111 companies. The most numerous group in this sector is small enterprises which constitute more than 95\% of the enterprises from the total number of firms in this sector." (the Ministry of Agriculture report for 2016)

The following findings were made as far as the stability of the performance measured by means of the accounting value added is concerned. The accounting value added for bakery, confectionery and other flour-based products (10.7) reached its maximum during the monitored period in 2009 (12,665 million CZK) and the drop to its minimum value then occurred in 2013. This was characterised by an average year-on-year drop of 400 million CZK to the value of 10,629.3 million CZK. There has been a year-onyear increase in the accounting value added at an average of 5\% since 2009.

The market characteristic is important for the analysis of stability. In the case of the 10.7 sectors, we can characterise the market as oligopolistic, in that it is dominated by large companies such as United Bakeries, Penam (sub-sector 10.71), Opavia-Lu (sub-sector 10.72) and Europasta SE (sub-sector 10.13).

The fall in added value was caused by a fall in revenues, while the fall in revenues was caused by a fall in the prices for the final products which has also been borne out by a fall in the industrial producers' price index. The firms were under pressure from the retail chains, while the higher price for cereals (the Ministry of Agriculture report for 2014) also had a (fundamental) influence on the fall in added value.

We can, therefore, characterise sector 10.7 as efficient, but unstable when measured using the accounting value added. This is due to the inputs (the developments in the price of wheat) and the weak bargaining position in relation to the customers (the chains). This weak bargaining position does not enable the transfer of the higher input prices to the sales price while maintaining the added book value. For this reason, the larger firms, which are able to create a sufficient "cushion" against the fluctuations in the input prices in relation to the volume of the added value (depending on the market share, will have greater stability in the given branch. Nevertheless, even these larger companies may also be threatened.

\subsubsection{The accounting value added in the other food product sector (10.8) and the industrial feed sector (10.9)}

The accounting value added for other food products (10.8) experienced an average year-on-year growth of $5.16 \%$ in the $2005-2011$ period. It has been gradually falling since 2011 when it reached its maximum (13,147.5 million CZK). The average year-on-year drop amounts to $3.13 \%$.

The accounting value added for industrial feeds (10.9) displayed a continuously increasing trend in the 2005-2014 period. The maximum value in 2014 amounted to 51,204.3 million CZK and it subsequently fell by $3.3 \%$.

The aforementioned shows that the 10.8 Other food products sector and the 10.9. Industrial feeds sector are stable sectors which do not display any "shock changes" and we can consider their development to date to be non-material due to the amount of the average year-on-year growth and the average year-onyear fall.

\subsection{Estimates of future development in the individual sectors}

The estimates of the future development of the individual sectors have been made on the basis of the construction of predictive models of exponential smoothing and they have been set out in Table 2 . In the following years, growth in the accounting value added can be expected in 5 sectors: CZ-NACE - 10.1, $10.2,10.5,10.8,10.9$. A fall has been predicted for the remaining 4 sectors. 
Table 2

Accounting value added to the food industry in CR

\begin{tabular}{|c|c|c|c|c|c|c|c|}
\hline \multirow{2}{*}{$\begin{array}{l}\text { State } \\
\text { CZ-NACE }\end{array}$} & \multicolumn{3}{|c|}{$\begin{array}{l}\text { Accounting value added } \\
\text { (mill. CZK) }\end{array}$} & \multicolumn{2}{|c|}{ Change $(\%)$} & \multicolumn{2}{|c|}{ Predictions* } \\
\hline & 2005 & 2010 & 2015 & $2010 / 2005$ & $2015 / 2010$ & 2017 & 2020 \\
\hline $\begin{array}{l}10.1 \text { Meat and meat } \\
\text { products }\end{array}$ & 9168.9 & 9204.4 & 9388.3 & +0.39 & +2.00 & $\uparrow 9101.8$ & $\uparrow 9167.6$ \\
\hline $\begin{array}{l}10.2 \\
\text { crustaceans } \\
\text { and molluscs }\end{array}$ & 351.8 & 428.8 & 385.4 & +21.89 & -10.12 & $\uparrow 326.8$ & $\uparrow 329.6$ \\
\hline $\begin{array}{l}10.3 \text { Fruits and } \\
\text { vegetables }\end{array}$ & 1617.5 & 1509.0 & 1445.8 & -6.71 & -4.19 & $\downarrow 1395.7$ & $\downarrow 1344.2$ \\
\hline $\begin{array}{l}10.4 \text { Vegetable and } \\
\text { animal oils and fats }\end{array}$ & 1982.6 & 1089.4 & 1256 & -45.05 & +15.29 & $\downarrow 1050.6$ & $\downarrow 832.7$ \\
\hline 10.5 Dairy products & 4682.6 & 5317.1 & 5518.6 & +13.55 & +3.79 & $\uparrow 6133.7$ & $\uparrow 6378.6$ \\
\hline $\begin{array}{l}10.6 \text { Mill and starch } \\
\text { products }\end{array}$ & 1830.4 & 1852.9 & 1537.4 & +1.23 & -17.03 & $\downarrow 1541.0$ & $\downarrow 1453.1$ \\
\hline $\begin{array}{l}10.7 \text { Bakery and } \\
\text { confectionery with } \\
\text { other flour-based } \\
\text { products }\end{array}$ & 12048.1 & 12136.7 & 11636.3 & +0.74 & -4.12 & $\downarrow 11529.4$ & $\downarrow 11405.9$ \\
\hline $\begin{array}{l}10.8 \text { Other food } \\
\text { products }\end{array}$ & 9720.3 & 12096.7 & 11576.5 & +24.45 & -4.3 & $\uparrow 11963.3$ & $\uparrow 12520.2$ \\
\hline 10.9 Industrial feeds & 4104.3 & 6148.1 & 6757.5 & +49.80 & +9.91 & $\uparrow 7559.1$ & $\uparrow 8355.1$ \\
\hline
\end{tabular}

Source: the Ministry of Agriculture reports for 2016 and 2011

*Own estimates based on Holt and Brown exponential smoothing

The overall view of the changes in the structure of the reported accounting value added in the food industry in 2005 and 2015 has been summarised in Fig. 1. As it shows, the greatest structural changes can be designated as the increased share of the accounting value added from industrial feeds in the total value added for the food industry (by almost 5\%), the increased share of the accounting value added from other food products in the total accounting value added for the food industry (by more than $2 \%$ ), the reduction of the accounting value added from vegetable and animal oils and fats in the total value added for the food industry (by just under 2\%) and the reduction of the share of the accounting value added for dairy products and starch products in the total value added for the food industry (by $1 \%$ ). The absolute values of the reported accounting value added including the predictions have been summarised in Table 2 .

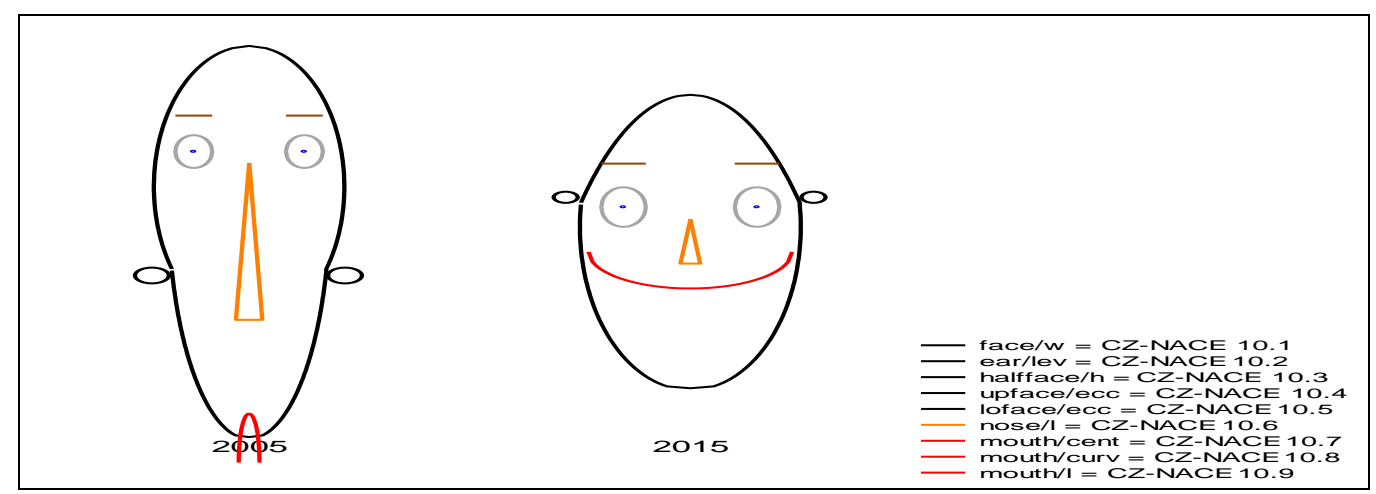

Figure 1. Icon plot (Chernoff Faces) of the accounting value-added structure for the food industry in the Czech Republic (2005 and 2015)

Source: the Ministry of Agriculture reports for 2016 and 2011 


\section{CONCLUSION}

As is clear from the realised statistical analyses, the greatest accounting value added in the food industry has been achieved by sector 10.7 - Bakery, confectionery and other flour-based products and sector 10.8 - Other food products, which is highly segmented and usually processes products of plant origin. The share of these two groups in the entire CZ-NACE section 10 amounts to almost $50 \%$. Along with meat and meat products (10.1), industrial feeds (10.9) and dairy products (10.5), they account for almost $91 \%$ of the total accounting value added for the food industry of the CR.

The beginning of the economic slump in the period from 2005 to 2015 started for most of the evaluated sectors in 2010 within the context of the economic crisis. Thereafter, a certain revival occurred, albeit with fluctuations in individual sectors. The chosen predictive adaptive models predict an increase in the accounting value added for the aforementioned sectors up to 2020, with the exception of bakery, confectionery and other flour-based products. The production of food products traditionally represents both a significant industrial and market segment. The tendencies and regulations described above give rise to the preconditions for prospective performance and stability in the majority of the sectors in the food industry of the CR.

Further research in the food industry and its individual sectors will focus on the impact subsidies have on performance and on the search for combinational methodologies for the measurement of performance that will take into account both soft and hard factors in order to take into consideration the specifics of the invididual sectors. The research will also aim to determine the impact of public promotion on the performance of individual sectors.

\section{ACKNOWLEDGEMENT}

This paper has received institutional support for long-term strategic development from the University of Finance and Administration research organization in 2019.

\section{REFERENCES}

Baker, G. A. (2003). Strategic planning and financial performance in the food processing sector. Review of Agricultural Economics, 25(2), 470-482.

Bašek, V. et al. (2010). České zemédèlství šest let po vstupu do evropské unie (výžkumná studie), Ústav zemědělské ekonomiky a informací. Praha, ISBN 978-80-86671-81-9.

Blažková, I. (2016). Convergence of market concentration: evidence from Czech food processing sectors. AGRIS online Papers in Economics and Informatics, 8(665-2016-45134), 25-36.

Curran, D. (2012). British regional growth and sectoral trends: global and local spatial econometric approaches. Applied Economics, 44(17), 2187-2201.

Daniloska, N. (2016). Concept of value-added in agriculture as a response to competitive marketplace. Економски Passoj-Economic Development, 18(1-2), 115-124.

Formánek, T. (2019). GDP per capita in selected EU countries: Economic growth factors and spatio-temporal interactions examined at the NUTS2 level. Journal of Interanational Studies, 12(1), 119-133. doi:10.14254/2071$8330.2019 / 12-1 / 8$

Gupta, V. K., \& Kumar, P. V. V. (2013). Value-based accounting: A performance analysis of Indian industry. IUP Journal of Accounting Research \&o Audit Practices, 12(1), 7-20.

Hindls, R., Hronová, S., Seger, J., \& Fisher, J. (2008). Statistika pro ekonomy. Praha: Professional Publishing, ISBN 978-80-86946-43-6

Jankelová, N. Masar, D., \& Moricova, S. (2017). Risk factors in the agriculture branch. Agricultural Economics / Zemedelska Ekonomika, 6, 247-258. 
Kaasa, A. (2019). Determinants of individual-level social capital: Culture and personal values. Journal of International Studie, 12(1), 9-32. doi: 10.14254/2071-8330.2019/12-1/1

Kraftova, I., Mateja, Z., \& Prasilova, P. (2011). Economic performance: Variability of businesses within each industry and among industries. Engineering Economics, 22(5), 459-467.

Maciejewski, M., \& Wach, K. (2019). What determines export structure in the EU countries? The use of gravity model in international trade based on the panel data for the years 1995-2015. Journal of International Studies, 12(1), 151-167. doi:10.14254/2071-8330.2019/12-1/10

Mejstrikova, L., Mezera, J., \& Plasil, M. (2011). Positive and negative aspects of financial economic development in selected branches of the food industry of the CR in 2007-2009 as revealed by Spider analysis. Agris on-line Papers in Economics and Informatics, 3(665-2016-44861), 39-54.

Montgomery, D.C., Jennings, C.L., \& Kulahci, M. (2008). Introduction to Time Series Analysis and Forecasting, New Jersey: Willey-Interscience.

Muhammad, K., Mastuki, N., Darus, F., \& Ghani, E.K. (2019). Accuunting information system change in an agriculture company: Examination using burns and scapes Framework. Journal of International Studies, 12(1), 105-118. doi:10.14254/2071-8330.2019/12-1/7

Náglová, Z., \& Horáková, T., (2016). Influence of Qualitative factors on Quantitative Determinants in the Czech Meat Industry Economy Agris On-Line Papers in Economics \& Informatics, 8, 111-123.

Pang, S., H'ng, P., Chai, L., Lee, S., \& Paridah, M. T. (2015). Value added productivity performance of the Peninsular Malaysian wood sawmilling industry. BioResources, 10(4), 7324-7338.

Prášilová, M., Procházková, R., \& Hošková, P. (2016). Foodstuffs self-sufficiency of Czech Republic in the context of long-term structural changes in primary agricultural production. The 10th Anniversary International Conference INPROFORUM, 2016, s. 1-8. ISBN 978-80-7394-607-4, ISSN 2336-6788

Roger S., \& Leif, G. (2009). Process-based analysis of added value in forest product industries. Forest Policy and Economics, 11, 65-75.

Špička, J. (2013). The competitive environment in the dairy industry and its impact on the food industry. Agris on-line Papers in Economics and Informatics, 5(665-2016-44948), 89-102.

The Ministry of Agriculture (2007). Panorama potravinářského průmyslu 2006 http://eagri.cz/public/web/mze/potraviny/publikace-a-dokumenty/panorama-potravinarskehoprumyslu/panorama-potrav-prumyslu-2006.html (accessed Aug 10, 2017)

The Ministry of Agriculture (2008). Panorama potravinářského průmyslu 2007 http://eagri.cz/public/web/mze/potraviny/publikace-a-dokumenty/panorama-potravinarskehoprumyslu/panorama-potrav-prumyslu-2007.html (accessed Aug 10, 2017)

The Ministry of Agriculture (2011). Panorama potravinářského průmyslu http://eagri.cz/public/web/mze/ministerstvo-zemedelstvi/vyrocni-a-hodnotici-zpravy/panoramapotravinarskeho-prumyslu/panorama-potravinarskeho-prumyslu-2010.html (accessed Aug 10, 2017)

The Ministry of Agriculture (2014). Panorama potravinářského průmyslu 2013, Available: http://eagri.cz/public/web/mze/potraviny/publikace-a-dokumenty/panorama-potravinarskehoprumyslu/panorama-potravinarskeho-prumyslu-2013.html (accessed Aug 10, 2017)

The Ministry of Agriculture (2014). Panorama potravinářského průmyslu http:/ / eagri.cz/public/web/mze/potraviny/publikace-a-dokumenty/panorama-potravinarskehoprumyslu/panorama-potravinarskeho-prumyslu-2013.html (accessed Aug 10, 2017)

The Ministry of Agriculture (2015). Panorama potravinářského průmyslu 2014, Available: http://eagri.cz/public/web/mze/potraviny/publikace-a-dokumenty/panorama-potravinarskeho-prumysluprumyslu-2014.html (accessed Aug 10, 2017)

The Ministry of Agriculture (2016). Panorama potravinářského průmyslu 2015, Available: http://eagri.cz/public/web/mze/potraviny/publikace-a-dokumenty/panorama-potravinarskeho-prumysluprumyslu-2015.html (accessed Aug 10, 2017)

Volek, T., \& Novotná, M. (2015). Gross value added and total factor productivity in Czech sectors. Contemporary Economics, 9(1), 17-28. 